\title{
Pathology of the heart and conduction system in lymphoma and leukaemia
}

\author{
D C ALLEN, * JOAN M ALDERDICE, * PATRICIA MORTON, $\dagger$ R A B MOLLAN, \\ T C M MORRIST
}

From the *Histopathology Laboratory, †Cardiac Unit, and $\mid$ Haematology Department, Belfast City Hospital, and $\ddagger$ Department of Orthopaedic Surgery, Queen's University, Belfast

The clinical and pathological findings in two patients with non-Hodgkin's lymphoma and two patients with $\mathrm{T}$ helper cell prolymphocytic leukaemia affecting the heart are described. All four patients had extensive malignant disease, with infiltration of multiple organs. Cardiac infiltration varied from microscopic foci in one case, to grossly identifiable tumour deposits destroying and replacing normal heart structures in three cases. Two patients with infiltration of the conduction system had abnormal electrocardiograms and cardiac dysfunction: one died suddenly, and the other died in heart failure. A third patient with widespread cardiac lymphoma did not show any electrocardiographic abnormalities or dysfunction. Clinicians should be aware of the possibility of cardiac and conduction system disease, particularly in the light of the evolution of specific antitumour chemotherapeutic agents.

There is growing awareness of both the pathological appearances and the clinical effects of infiltration of the heart in diseases affecting several organs. Diminished myocardial function and the production of conduction defects have been reported in systemic amyloidosis, ${ }^{1-6}$ Wegener's granulomatosis, ${ }^{7-9}$ systemic lupus erythematosus, ${ }^{10}$ rheumatoid disease, ${ }^{11}$ polyarteritis nodosa, ${ }^{1213}$ and scleroderma. ${ }^{14}$ Metastatses occur more frequently than primary tumours in the heart; bronchogenic carcinoma, malignant lymphoma, and leukaemia share a particular tendency to cardiac infiltration. ${ }^{15}$ This study illustrates the clinical and pathological findings in four patients with lymphoma and leukaemia, resulting in cardiac disease.

\section{Patients and methods}

After full necropsies and careful examination of the hearts in four patients the conduction system tissues were dissected. The sinus and atrioventricular nodal areas were identified and serial blocks taken. Multiple sections were stained with haematoxylin and eosin and van Gieson's solution.

The table shows the clinical and pathological findings. All four patients had widespread lymphomatous or leukaemic dissemination, with grossly identifiable cardiac disease in cases 1, 2, and 3. Cases 1 and 2 had associated electrocardiographic and dysfunctional abnormalities. Case 1 showed extensive interatrial septal deposits (fig 1), sinus and atrioventricular nodal replacement, and infiltration of the His bundle, with degeneration of the conducting myofibrils (fig 2); the proximal bundle branches were also affected (fig 3). Case 2 showed leukaemic cells in the epicardium, and in the autonomic nerves and

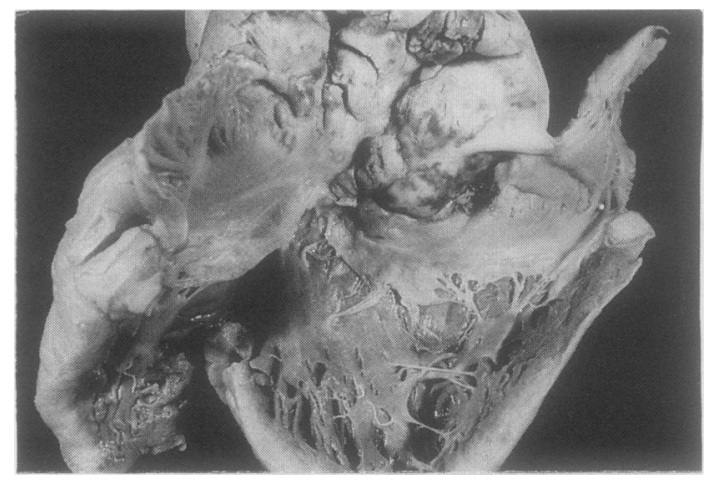

Fig 1 Case 1: opened right atrium and ventricle show pale, nodular tumour deposits elevating endocardium of interatrial septum and thickening atrial walls. 
Table Clinical and pathological findings in four patients with cardiac lymphoma and leukaemia

\begin{tabular}{|c|c|c|c|c|c|c|}
\hline \multirow{2}{*}{$\begin{array}{l}\text { Case } \\
\text { No }\end{array}$} & \multirow{2}{*}{$\begin{array}{l}\text { Age and } \\
\text { Sex }\end{array}$} & \multirow[b]{2}{*}{ Diagnosis } & \multirow[b]{2}{*}{ Clinical course } & \multirow[b]{2}{*}{$E C G$} & \multicolumn{2}{|l|}{ Cardiac disease } \\
\hline & & & & & General & Conducting tissues \\
\hline 1 & $\begin{array}{l}63 \\
\text { Female }\end{array}$ & $\begin{array}{l}\text { Non-Hodgkin's } \\
\text { lymphoma }\end{array}$ & Sudden death & $\begin{array}{l}\text { Atrial flutter } \\
\text { atrioventricular } \\
\text { dissociation; } \\
\text { incomplete right } \\
\text { bundle branch } \\
\text { block }\end{array}$ & $\begin{array}{l}\text { Nodular tumour } \\
\text { deposists atrial } \\
\text { walls and } \\
\text { interatrial septum }\end{array}$ & $\begin{array}{l}\text { Tumour } \\
\text { replacement SA } \\
\text { node, AV node, } \\
\text { His bundle and } \\
\text { proximal bundle } \\
\text { branches }\end{array}$ \\
\hline 2 & $\begin{array}{l}81 \\
\text { Male }\end{array}$ & $\begin{array}{l}\text { T helper cell } \\
\text { prolymphocytic } \\
\text { leukaemia }\end{array}$ & $\begin{array}{l}\text { Initial response to } \\
\text { deoxycoformycin; } \\
\text { refractory cardiac } \\
\text { failure }\end{array}$ & $\begin{array}{l}\text { Atrial fibrillation, } \\
\text { left anterior hemi- } \\
\text { block, wide QRS } \\
\text { complexes, ST/T } \\
\text { wave changes }\end{array}$ & $\begin{array}{l}\text { Pale tumour } \\
\text { deposits in } \\
\text { pericardium, atrial, } \\
\text { and ventricular } \\
\text { myocardium }\end{array}$ & $\begin{array}{l}\text { Tumour } \\
\text { superficially in SA } \\
\text { node, superficial to } \\
\text { AV node; origin, } \\
\text { proximal mid- } \\
\text { course left bundle } \\
\text { branch }\end{array}$ \\
\hline 3 & $\begin{array}{l}74 \\
\text { Female }\end{array}$ & $\begin{array}{l}\text { Non-Hodgkin's } \\
\text { lymphoma }\end{array}$ & $\begin{array}{l}\text { Died-chest } \\
\text { infection }\end{array}$ & $\begin{array}{l}\text { Sinus rhythm, } \\
\text { atrial ectopics }\end{array}$ & $\begin{array}{l}\text { Diffuse tumour } \\
\text { pericardium, } \\
\text { myocardium, both } \\
\text { ventricles }\end{array}$ & $\begin{array}{l}\text { Tumour } \\
\text { superficially in SA } \\
\text { node, upper bundle } \\
\text { branches }\end{array}$ \\
\hline 4 & $\begin{array}{l}74 \\
\text { Female }\end{array}$ & $\begin{array}{l}\text { T helper cell } \\
\text { prolymphocytic } \\
\text { leukaemia }\end{array}$ & $\begin{array}{l}\text { Initial response to } \\
\text { deoxycoformycin; } \\
\text { deteriorating } \\
\text { renal function }\end{array}$ & $\begin{array}{l}\text { Sinus } \\
\text { tachycardia }\end{array}$ & $\begin{array}{l}\text { Focal infiltration } \\
\text { epicardium of } \\
\text { atrioventricular } \\
\text { sulci }\end{array}$ & \\
\hline
\end{tabular}

$\mathrm{SA}=$ sinoatrial (sinus) node; $\mathrm{AV}=$ atrioventricular node.

ganglia overlying, and associated with, the superficial aspects of the sinus node (fig 4). ${ }^{16}$ The left bundle branch was also diseased (fig 5).

\section{Discussion}

Roberts et al $^{17}$ carried out a necropsy study of 196 patients with malignant lymphoma and found cardiac disease in 48 cases. Of the lymphoma subtypes, cardiac infiltration was seen in $16 \%$ of the patients with Hodgkin's disease, $25 \%$ of the patients with nonHodgkin's lymphoma, and $33 \%$ of the patients with mycosis fungoides. Of these 48 patients, lymphoma was identified grossly in the heart in 27 cases and found on microscopical examination alone in 21 . The most common disease sites were the pericardium and epicardial fat, particularly in the atrioventricular sulci. Nodular deposits within the cardiac chambers were also found. There were electrocardiographic abnormalities in $66 \%$, and these were mainly sinus tachycardia and ST-T wave changes. When they compared these patients with a control group, they found that in only few cases were the electrocardiographic changes attributable to lymphoma. In five patients the degree of tumour infiltration was sufficient to cause either congestive heart failure due to myocardial lymphoma, or electrocardiographic abnormalities because of right atrial and interatrial septal tumour deposits. Two cases of mycosis fungoides had several abnormalities as a result of right atrial disease, including atrial flutter, fibrillation, right bundle branch block, and atrioventricular dissociation. They concluded that there was a noticeable discrepancy

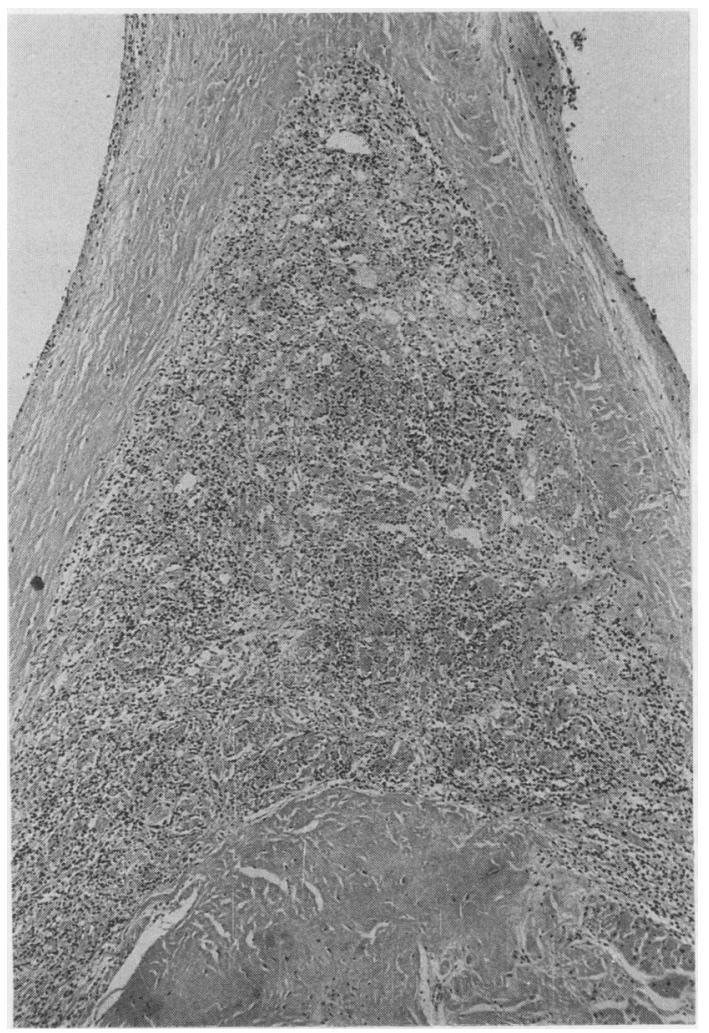

Fig 2 Case 1: triangular shaped His bundle, sitting in surrounding central fibrous body, shows diffuse lymphomatous infiltration and degenerate conducting myofibrils. 


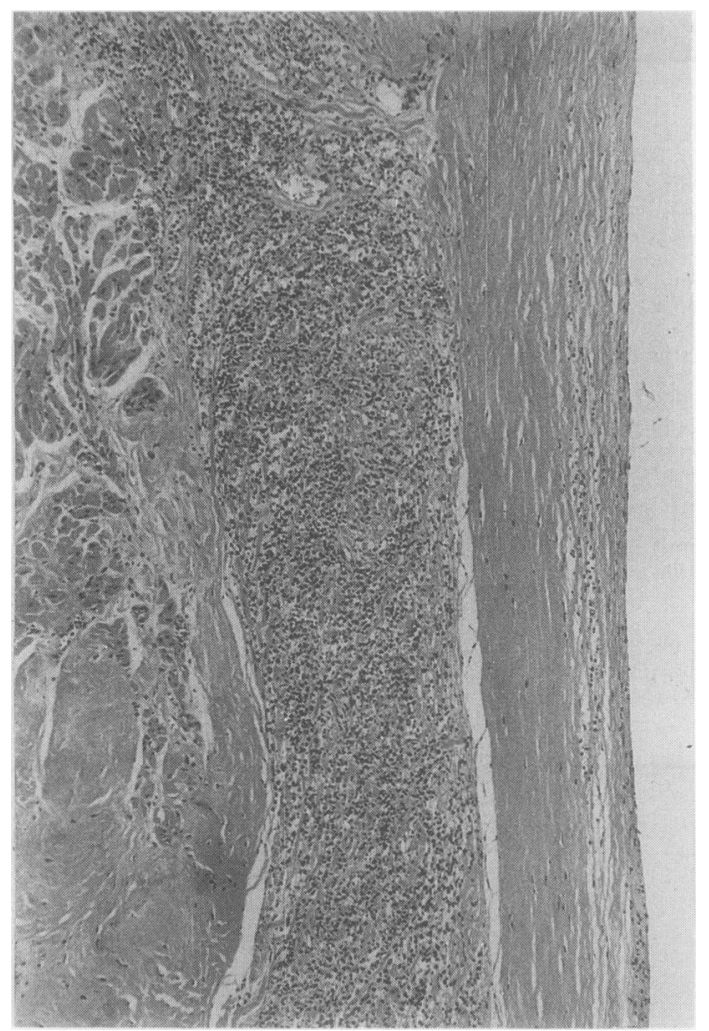

Fig 3 Case 1: proximal bundle branch tumour infiltration. Endocardium (right), interventricular septal muscle (left).

between the incidence of cardiac lymphoma and the lack of dysfunction it produced.

This is reflected in case 3 of the present study, where despite extensive cardiac lymphoma-even seen on gross examination of the myocardium - and focal sinus node and bundle branch disease, there was no clinically important cardiac dysfunction. This contrasts with case 1 , which shows many of the typical features of cardiac lymphoma. The pericardium and epicardium were thickened by tumour, and the atria contained pale, nodular deposits, particularly in the interatrial septum. These sites showed partially necrotic tumour, which obliterated and replaced the sinus and atrioventricular nodes, and diffuse lymphomatous infiltration of the common His bundle and proximal bundle branches. This resulted in atrial flutter, incomplete right bundle branch block, and atrioventricular dissociation. Nodular epicardial, right atrial, and interatrial septal tumour masses have been noted in Hodgkin's disease, ${ }^{18}$ non-Hodgkin's lymphoma, ${ }^{15,19,20}$ and Burkitt's lymphoma. ${ }^{21}$ These produced symptomatic Stokes Adams attacks with atrioventricular block, ${ }^{18}$ and complete heart block was seen on electrocardiography. ${ }^{15,20,21}$ Infiltration and destruction of conducting myofibres were found in the atrioventricular node ${ }^{20,21}$ and the common His bundle, ${ }^{18,20}$ but these findings were not illustrated. Sudden death has been described in patients with cardiac lymphoma, due to rupture of the infiltrated myocardium, resulting in haemopericardium. ${ }^{19}$ Case 1 died unexpectedly perioperatively, and no doubt conduction system disease contributed to this; as similarly, in sudden death this occurred in other diseases such as amyloidosis ${ }^{4,5.6}$ or sarcoidosis. ${ }^{22}$

Leukaemic infiltration of the atrioventricular septa, with resultant atrioventricular dissociation was described in $1949 ;^{23}$ in 1950 Mahaim and Rossier reported infiltration of the sinus node and His bundle by myeloid leukaemia in a patient with progressive atrioventricular block. ${ }^{24}$ Complete heart block in an 8 year old leukaemic patient has also been reported. ${ }^{25}$ Widespread prolymphocytic leukaemia with variable

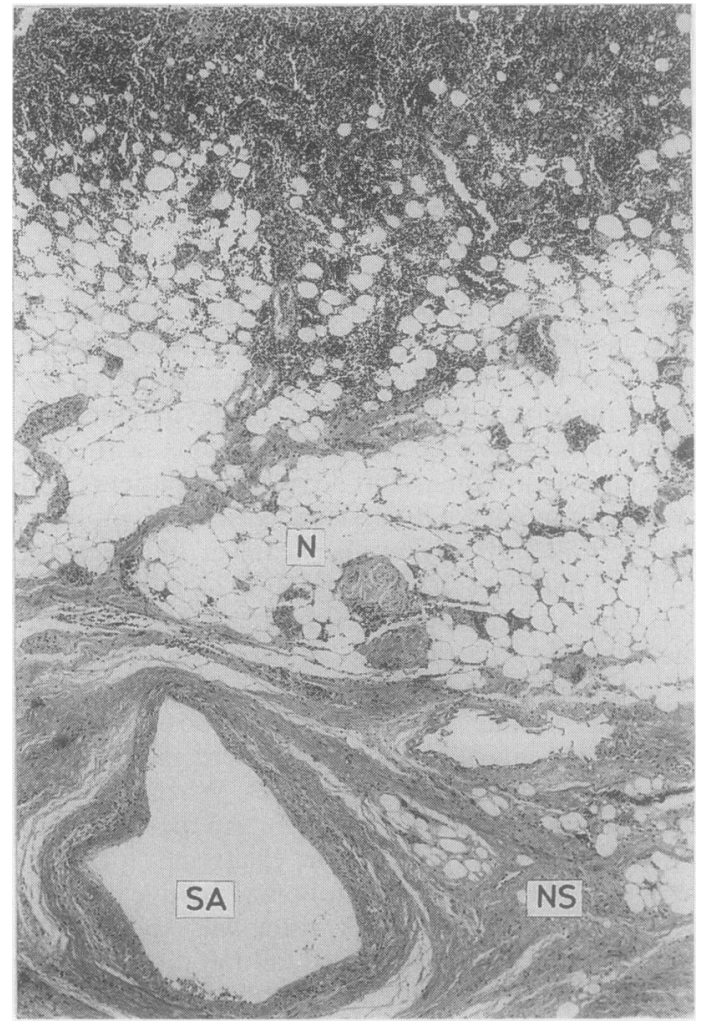

Fig 4 Case 2: heavy infiltration by prolymphocytic leukaemic cells of epicardial fat (top) and nerves $(N)$ lying superficial to periphery of sinus node. Nodal substance (NS) shows light, focal infiltration around sinus nodal artery $(S A)$. 


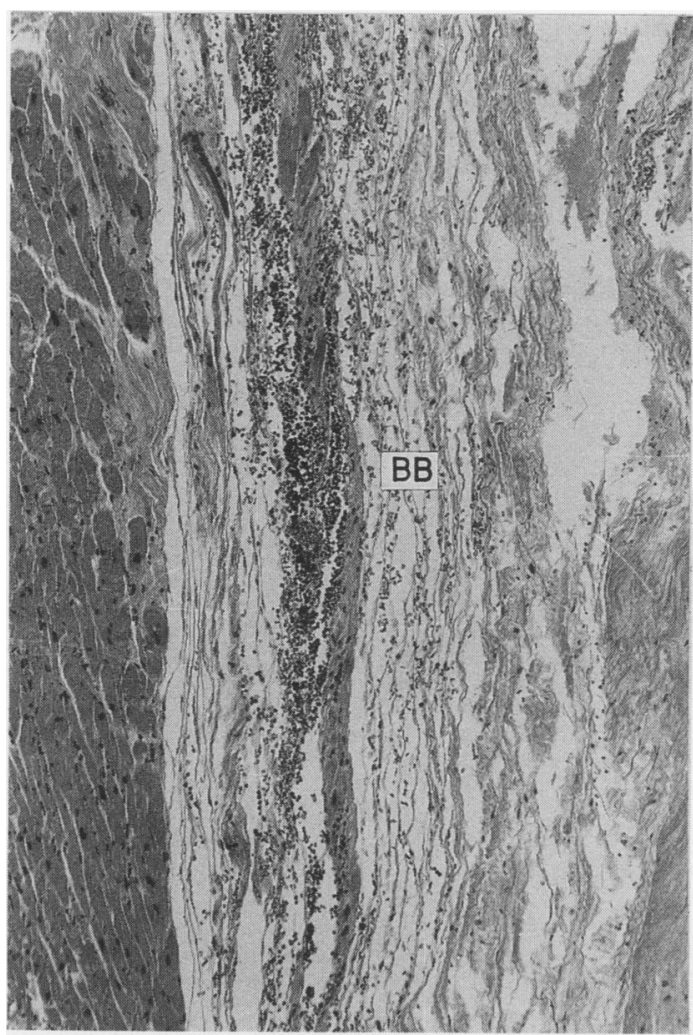

Fig 5 Case 2: tumour infiltration of proximal left bundle branch (BB). Subendocardium (right of field), interventricular myocardium (left).

degrees of cardiac infiltration occurred in two cases ( 2 and 4 ). Case 2 had extensive cardiac disease in the myocardium and conduction system, resulting in refractory cardiac failure and an abnormal electrocardiogram. Heavy infiltration of the epicardial fat and nerves overlying the sinus node, as well as direct nodal disease, suggests that local nerve damage may have caused rhythm disturbance. ${ }^{926}$ An awareness of the possibility of cardiac dysfunction induced by tumour is of considerable practical importance, and is emphasised by case 2 . Deoxycoformycin should not be given if the glomerular filtration rate is less than $60 \mathrm{ml} /$ minute, but as the leukaemia affected cardiac function, and thus renal function, a case could be made for the use of deoxycoformycin in a reduced dose as a genuine attempt to improve cardiac function and minimise conduction abnormalities. This principle may be applied to other chemotherapeutic agents in cardiac lymphoma or diseases such as Wegener's granulomatosis, in which complete heart block regressed to right bundle branch block, following successful treatment of the clinical exacerbation with temporary pacing and cyclophosphamide. ${ }^{7}$

In conclusion, the clinician should be aware of the existence and possibility of treating cardiac disease in malignant lymphoma and leukaemia. The electrocardiogram is not a sensitive indicator of cardiac infiltration; nevertheless, electrocardiographic abnormalities in patients with these diseases may sometimes be an indication for further invasive investigation, including possibly, myocardial biopsy, to establish a definitive diagnosis with a view to administering specific treatment.

\section{References}

1 Wessler S, Freedburg AS. Cardiac amyloidosis; electrocardiographic and pathologic observations. Arch Intern Med 1948;82:63-74.

2 James TN. Pathology of the cardiac conduction system in amyloidosis. Ann Intern Med 1966;65:28-36.

3 Bharati, S, Lev M, Denes P, et al. Infiltrative cardiomyopathy with conduction disease and ventricular arrhythmia: electrophysiologic and pathologic correlations. Am J Cardiol 1980; 45:163-73.

4 Lumb, G, Shacklett RS. Human cardiac conduction tissue lesions. Am J Pathol 1960;36:411-29.

5 Wright JR, Calkins E. Clinical-pathologic differentiation of common amyloid syndromes. Medicine 1981;60:429-48.

6 Allen DC, Doherty CC. Sudden death in a patient with amyloidosis of the cardiac conduction system. Br Heart $J$ 1984; 51:233-6.

7 Forstot JZ, Overlie PA, Neufeld GK, Harmon CE, Forstot SL. Cardiac complications of Wegener's granulomatosis: a case report of complete heart block and review of the literature. Semin Arthritis Rheum 1980;10:148-54.

8 Longauer $\mathrm{F}$, Tákac $\mathrm{M}$, Halásová $\mathrm{K}$. Úber Schädigung des Reizleitungssystems bei Wegenerscher Granulomatose. Zeitschrift für Kreislaufforschung 1969;58:412-21.

9 Allen DC, Doherty CC, O'Reilly DPJ. Pathology of the heart and the cardiac conduction system in Wegener's granulomatosis. Br Heart $J$ 1984;52:674-8.

10 James TN, Rupe CE, Monto RW. Pathology of the cardiac conduction system in systemic lupus erythematosus. Ann Intern Med 1965;63:402-10.

11 Harris M. Rheumatoid heart disease with complete heart block. J Clin Pathol 1970;23:623-6.

12 James TN, Birk RE. Pathology of the cardiac conduction system in polyarteritis nodosa. Arch Intern Med 1966;117:561-7.

13 Thiene G, Valente M, Rossi L. Involvement of the cardiac conducting system in panarteritis nodosa. Am Heart J 1978;95: 716-24.

14 Lev M, Landowne M, Matchar JC, Wagner JA. Systemic scleroderma with complete heart block: report of a case with a comprehensive study of the conduction system. Am Heart J 1966; 72:13-24.

15 Brick IB, Greenfield M. Reticulum cell sarcoma with cardiac metastasis: report of two cases with antemortem diagnosis of one. Am Heart J 1947;34:599-611.

16 El'Agnaf MR, Ennis KE, Morris TCM, Robertson JH, Markey G, Alexander HD. Successful remission induction with deoxycoformycin in elderly patients with $\mathrm{T}$ helper prolymphocytic leukaemia. Br J Haematol 1986;63:93-104.

17 Roberts WC, Glancy DL, DeVita VT. Heart in malignant lymphoma (Hodgkin's disease, lymphosarcoma, reticulum cell sarcoma and mycosis fungoides): a study of 196 autopsy cases. Am J Cardiol 1968;22:85-107.

18 Goggio AF, Harkness JT, Palmer WS. Stokes-Adams syndrome in Hodgkin's granuloma. JAMA 1961;176:687-9. 
19 Keat ECB, Twyman VR. Cardiac involvement in lymphosarcoma with spontaneous rupture of the heart. Br Heart J 1955; 17:563-5.

20 Kellaway G, Gardner DL. Metastatic reticulum cell sarcoma of the heart causing complete heart block. Scott Med J 1959;4: 575-80.

21 Cole TO, Attah EB, Onyemelukwe GC. Burkitt's lymphoma presenting with heart block. Br Heart J 1975;37:94-7.

22 James TN. Sarcoid heart disease. De Subitaneis Mortibus XXV. Circulation 1977;56:320-6.

23 Dresdale DT, Spain D, Perez-Pina F. Heart block and leukemic cell infiltration of interventricular septum of heart. Am J Med 1949;6:530-3.
24 Mahaim I, Rossier PH. Leucémie myéloide aiguë, diathese hémorragique, bloc auriculo-ventriculaire. Lésions du tissu spécifique. Cardiologia (Basel) 1950;15:196-208.

25 Gupte S. Acute leukemia with complete heart block. Am J Dis Child 1977:131:926.

26 James TN. Apoplexy of the heart. De Subitaneis Mortibus XXVIII. Circulation 1978:57:385-91.

Requests for reprints to: Dr Derek Allen, Histopathology Laboratory, Belfast City Hospital, BT9 7AD, Northern Ireland. 